\title{
Agricultural exports and retaliatory trade actions: An empirical assessment of the 2018/2019 trade conflict
}

\author{
Jason H. Grant ${ }^{1}$ | Shawn Arita ${ }^{2}$ | Charlotte Emlinger ${ }^{1}$ | \\ Robert Johansson $^{2}$ | Chaoping Xie ${ }^{3}$
}

${ }^{1}$ Center for Agricultural Trade, Department of Agricultural \& Applied Economics, Virginia Tech, Blacksburg, Virginia, USA

${ }^{2}$ Office of the Chief Economist, U.S. Department of Agriculture, Washington, District of Columbia, USA

${ }^{3}$ College of Economics and Management, Nanjing Agricultural University, Nanjing, China

\section{Correspondence}

Chaoping Xie, College of Economics and Management, Nanjing Agricultural

University, Nanjing, China.

Email: xiecp@njau.edu.cn

\section{Funding information}

Priority Academic Program Development of Jiangsu Higher Education Institutions (PAPD); National Science Foundation of China, Grant/Award Numbers: 71934005, 71903090; Office of the Chief Economist, Grant/Award Number: 58-0111-19-013

Editor in Charge: Daniel Petrolia

\begin{abstract}
We estimate the ex-post agricultural trade impacts of retaliatory measures imposed by foreign countries in response to United States' Section 232 and 301 tariffs using a theoretically consistent, monthly, product line gravity equation. Retaliation led to significant US agricultural export losses of $\$ 13.5$ to $\$ 18.7$ billion on an annualized basis. Considerable heterogeneity exists in the average treatment effect of retaliation. First, retaliatory trade actions presented a strong within-year seasonal impact. Nearly $70 \%$ of aggregate trade losses occurred during the US's peak export marketing season. Second, U.S. trade losses were particularly pronounced on homogeneous bulk commodities, whereas product differentiation dampened the impact of retaliation. Third, with few exceptions, the counterfactually estimated direct trade losses line up well with the U.S. Department of Agriculture's (USDA) trade damage estimates for trade aid programs distributed to farmers impacted by the trade dispute. Finally, we find little evidence that U.S. exports were able to be reoriented to alternative, nonretaliating markets-an indication of high bilateral trade frictions and the destructive consequences of retaliatory trade actions.
\end{abstract}




\author{
K E Y W O R D S \\ gravity model, retaliation, trade aid programs, trade war \\ JEL C L A S S I F I C A T I O N \\ F14; Q17; Q18
}

\title{
BACKGROUND
}

The World Trade Organization (WTO) and its predecessor, the General Agreement on Tariffs and Trade (GATT 1947) were designed to promote a rules-based international trading system that discourages the use of protectionist policies set unilaterally by individual countries. The GATT/WTO, however, has suffered one of its deepest impasses in modern history (Baldwin, 2016; Bown \& Irwin, 2018; Grant \& Boys, 2012; Orden, 2020). The Doha Round, launched in 2001 with the goal of building on the Uruguay Round, has dragged on for nearly two decades. The requiem for the Doha Round seems to have been written at this point following unsuccessful negotiations in Geneva in 2008, Bali in 2013, and Nairobi in 2015. The failure to realize the promise of the Doha Round set the stage for a return to protectionist tendencies that preceded the Uruguay Round.

The Great Recession of 2007-2009 marked one of the most significant economic downturns; however, the economic expansion period that followed was one of the longest on record. Many have documented the residual impacts of globalization promoting protectionist tendencies (Autor et al., 2016; Rodrik \& Di Tella, 2020). Others have noted the less-than-complete adherence to WTO commitments by member countries as another source of friction by developed countries that were frustrated by an uneven playing field (Grant \& Boys, 2012; Subramanian \& Wei, 2007). Perhaps it was not unsurprising, then, when in 2018, the global movement toward freer trade reversed course with the United States implementing a series of unilateral trade measures aimed to curtail imports, and to improve Chinese compliance with intellectual property rights and discriminatory trading practices underlying their WTO commitments (Amiti et al., 2019; Bown, 2018; Bown, 2019; Crowley, 2019). Retaliation to U.S. tariffs soon followed by six exporters: China, Canada, Mexico, the European Union (EU), Turkey, and India. Appendix A provides a summary of the trade dispute timeline and retaliatory trade actions imposed.

The abrupt reversal of United States' trade policy provides a unique opportunity to investigate the trade flow effects of retaliatory trade actions. Of particular significance, and one that bears little historical precedence, retaliation by China, Canada, Mexico, the EU, Turkey, and India targeted many U.S. agricultural products. ${ }^{1}$ This article quantifies the impact of retaliatory trade actions on United States exports of agricultural products. Specifically, we develop a disaggregated month-by-product bilateral trade flow database covering 81 countries from January 2016 through December 2019 to answer three related empirical questions: (a) To what extent did retaliatory trade actions reduce US agricultural exports? (b) To what extent is the retaliatory trade effect conditional on destination markets imposing the duties, homogeneous versus differentiated product types, within-year seasonality of US commodity exports, and high and low points of US-China trade relations? (c) From a policy perspective, how do the counterfactually estimated retaliatory trade effects line up with the U.S. Department of Agriculture's (USDA) damage estimates for trade aid programs distributed to producers affected by the trade war? 
Retaliatory trade actions impacting US agricultural exports were implemented in different phases, including periods of respite and deterioration, by multiple (six) countries, and on narrowly defined agri-food product categories. Variation in trade policy actions in country-pair-product-time space permits a relatively clean identification of trade effects using theoretically consistent econometric methods. The policy implications of our findings are important because ex-post empirical analyses not only enhance understanding of the often-heterogeneous trade impacts of retaliatory measures, they also help policymakers and trade negotiators design better policy programs in periods of disruptions to agricultural export markets.

\section{INSIGHTS FROM RECENT ASSESSMENTS OF THE TRADE WAR}

The trade war became the focal point of a growing body of empirical literature exploring the relationship between higher tariffs and import prices and volumes. Fajgelbaum et al. (2020) found that U.S. exports subject to retaliation fell 9.9\% within products. Amiti et al. (2019) estimate that the 2018 tariffs imposed by the US resulted in a reduction of real income by $\$ 1.4$ billion per month, with the incidence falling squarely on importers and consumers. ${ }^{2}$ Employing a longer panel of monthly trade data, Amiti et al. (2020) demonstrate that US tariffs caused foreign exporters to lower their prices into the US market for some products such as steel, with exporters bearing up to one-half the incidence of US steel tariffs. Cavallo et al. (2019) corroborate the tariff pass-through at the border; however, the story is mixed at the retail level. Waugh (2019) investigated monthly automobile sales at the county level and found that counties in the upper quartile of the retaliatory-tariff distribution experienced a 3.8 percentage point decline in consumption growth.

Fewer studies have investigated the impacts of retaliation against US agricultural exports. Regmi (2019) provides a summary of the trade dispute on US and global agricultural trade. Marchant and Wang (2018) edited a collection of special issue articles projecting the ex-ante impacts of the US-China trade dispute (Taheripour \& Tyner, 2018). Janzen and Hendricks (2020) find that the trade aid program more than compensated farmers in the short run but not necessarily in the long run if US exports struggle to re-establish the Chinese market. Grant and Sydow (2019) edited a special issue of preliminary ex-post impacts of the trade dispute on agricultural trade (Grant et al., 2019), soybeans (Adjemian, Arita et al. 2019; Hitchner et al., 2019), cotton (Muhammad et al., 2019), tree nuts (Sumner et al., 2019), farm programs (Westhoff et al., 2019), and pork (Nti et al., 2019). Using an event study framework similar to Fajgelbaum et al. (2020), Carter and Steinbach (2020) conducted a 12-month before-and-after study of retaliation against U.S. agricultural products. Their results suggest retaliation lowered US agricultural exports by $\$ 15$ billion in aggregate with the US picking up minimal gains in nonretaliating markets.

\section{ESTIMATION SETUP}

The empirical assessment of the 2018/2019 trade war relies on a monthly gravity model of disaggregated product-specific bilateral trade relationships to estimate partial direct and indirect effects of trade retaliation. ${ }^{3}$ The Supplementary Technical Appendix provides more details on 
the model and estimation setup. Specifically, we assess the effect of retaliatory measures on US exports along three dimensions:

i. Retaliation effect: impacts of retaliatory trade actions on US exports to a retaliatory partner. All else equal, US export sales are expected to decrease to trade partners imposing retaliatory trade actions due to the higher trade costs.

ii. Product, country, and time specific components of retaliation: all else equal, the direct effect of retaliation likely depends on the country imposing the measures, product types, and within-year seasonality of commodity exports.

iii. Counterfactual Comparison of Product-Line Effects and USDA Trade Aid Programs: comparison of counterfactually estimated, product-by-product trade effects projected off a 2017 baseline to those of USDA's trade aid programs (calculated ex-ante) distributed to famers affected by the trade dispute.

To briefly summarize our estimation approach, denote exporting (importing) countries as $i(j)$ and products, months, and years as $k, m$, and $t$, respectively. Using monthly panel data from January 2016 through December 2019 of bilateral-product-month relationships (ijkm), estimation of the trade effect of retaliation on U.S. agricultural exports is as follows:

$$
X_{i j k m t}=\exp \left\{\mu_{i j k m}+\pi_{i t}+\varphi_{j t}+\kappa_{k t}+\xi_{m t}+\gamma_{1} \text { retaliation }_{i j k m t}\right\}+\varepsilon_{i j k m t}
$$

where, exp denotes the exponential function, $X_{i j k m t}$ is the value of bilateral trade between exporting country $i$, importing country $j$, 6-digit product code $k$ of the Harmonized System (HS), month $m(m=1,2, \ldots 12)$, and year $t(t=2016,2017, \ldots$ 2019). Crucially, Equation (1) contains a comprehensive set of exporter-importer-product-month specific fixed effects, $\mu_{i j m k}$, designed to absorb all time-invariant product-and-month specific bilateral trade cost or promoting effects. Such trade cost factors include existing nontariff measures (see Grant and Arita, 2017; Ning and Grant, 2019), transportation costs (i.e., distance), existing free trade agreements (i.e., US-Korea, China-Australia, etc.), bilateral applied tariffs, time-invariant natural, cultural and geographical factors, as well as within-year monthly seasonality of supply and demand of product $\mathrm{k}^{4}{ }^{\mathrm{ret}}$ aliation $_{i j k m t}$ is a time-varying dichotomous variable equal to one if exporter $i$ is the US and importer $j$ imposes retaliatory measures on product $k$ in month $m$ and year $t$, and zero otherwise.

We use dichotomous (i.e., dummy) variables to quantify the impact of retaliatory tariffs as opposed to changes in tariff rates for two reasons. First, China's retaliatory trade actions often went beyond tariffs to include announced prohibitions on purchases of US agricultural products. For example, on August 5, 2019 China announced that its state-owned enterprises (SOEs) would "halt" further purchases of US agricultural products. ${ }^{5}$ Second, because they impact prices directly, tariffs have a very specific structural interpretation (i.e., elasticity) in almost all theories underlying the gravity equation (see Head \& Mayer, 2014; Peterson et al., 2013; Yotov et al., 2016). The coefficient of interest is $\gamma_{1}$ measuring direct effect of retaliation on US agricultural exports.

In addition to $\mu_{i j m k}$, we also include importer-year $\left(\varphi_{j t}\right)$, exporter-year $\left(\pi_{i t}\right)$, product-year $\left(\kappa_{k t}\right)$, and month-year $\left(\xi_{m t}\right)$ fixed effects, which are time varying, but not bilateral-specific, to control for changes in a country's overall inward or outward multilateral agri-food trade 
resistance $(i t, j t)$, year-to-year fluctuations in global commodity prices $(k t)$ and possible monthby-year $(m t)$ shifts in agricultural trade patterns.

As suggested by Santos Silva and Tenreyro (2006, 2010, 2011), we adopt the Poisson-PseudoMaximum Likelihood PPML estimator because it retains the multiplicative theoretical structure of the gravity model. It is also robust to unknown patterns of heteroscedasticity and permits the inclusion of zero trade flows in estimation. Zero trade flows are important in the context of retaliatory trade actions: if U.S. exports are strictly positive prior to the onset of the trade dispute and fall to zero due to retaliation, omission of these policy-induced zero trade flows creates the classic sample selection bias leading to underestimation of trade impacts.

This analysis builds on the preliminary econometric assessments in Grant et al. (2019) and Carter and Steinbach (2020). In particular, we view product varieties as an origin-destinationproduct-month quadruplet (i.e., country-pair-by-product-by-month). Instead of using variation between retaliating and non-retaliating markets (Fajgelbaum et al. 2020; Carter \& Steinbach, 2020), we assess trade impacts within country-pairs-by-product-by-month. This nuance is important because it allows us to control for pre-existing distortions to agricultural trade that were largely unrelated to the trade dispute.

Two examples will help clarify this nuance, one based on product seasonality and the second, policy induced. First, China's in-season imports of US (Brazilian) soybeans following harvest in the northern (southern) hemisphere are two-three times more by value than its imports from any other country, even during the depths of the trade war. Exploiting variation between retaliating and nonretaliating destination markets would tend to understate the effect of China's retaliatory trade actions on US soybeans exports. Second, since 2003 (2015) China has effectively banned beef (poultry) imports from the US due to Bovine Spongiform Encephalopathy (BSE) (Avian Influenza) concerns (Grant \& Arita, 2017). While the US-China Phase One trade deal negotiated new market access for these two commodities, US beef and poultry exports to China remained near zero before and throughout the trade war. In this case, we do not want to attribute low (existing) Chinese beef and poultry imports from the US that remained low throughout the trade war to retaliatory tariffs using variation between retaliating and nonretaliating countries. The within $(i j k m)$ fixed effects are designed to capture pre-existing bilateral trade frictions at the product level when assessing the trade effects of retaliation.

\section{DATA}

Monthly bilateral imports and exports from January 2016 through December 2019 reported by 81 countries are retrieved from Trade Data Monitor. ${ }^{6}$ Appendix B lists the individual countries in the database along with their 2017 imports from the US. Canada, China, Mexico, Japan, and European Union (EU) are the top five importers of US agricultural products totaling \$81 billion in 2017. Among these top destination markets, Japan is the only importing country that did not impose retaliatory tariffs. Together, the six retaliating countries (China, Mexico, Canada, EU, Turkey, India) accounted for 57\% of US agricultural exports in 2017.

Reported exports, or "mirrored" flows, are used when the importer's reported imports are missing. This was the case for Vietnam and a few other countries in the raw data. One issue that arises in the use of reported imports and exports is that the former is based on delivered cost, insurance, freight (cif) value, whereas the latter are valued free on board ( $f o b)$. However, as long as we consistently use reported exports or reported imports throughout the sample for 
each $i j k m$ trade relationship, the fixed effects $\left(\mu_{i j m k}\right)$ will control for differences in cif and fob valuations.

The sample includes 753 commodities at the six-digit level of product codes (HS2012). ${ }^{7}$ Appendix C provides a concordance of HS6-digit agricultural product codes into BICO sectors. We conduct the analysis at the HS6-digit product level as this is the finest level of disaggregation that can be compared internationally. The direct effect of retaliation is dynamically coded by country-pair-product-month using official national sources detailing products impacted and time periods in which retaliation was imposed ${ }^{8}$ (Appendix D). ${ }^{9}$

Table 1 summarizes US bilateral trade flow levels and changes for total agricultural trade and the subset of products targeted by retaliation. China's agricultural imports of targeted commodities from the U.S. almost halved from $\$ 22.5$ billion in 2017 to $\$ 14.7$ billion in 2018 and $\$ 13.1$ billion in 2019 (columns 2, 7, and 8, Table 1). EU imports of targeted products from the US decreased by $33 \%$, from $\$ 900$ million in 2017 to $\$ 600$ million in 2019 . Conversely, for the remaining countries-Canada, Mexico, Turkey, and India - the direct effect of retaliation is less evident in aggregate. With the exception of China (98\%) and India (43\%), the retaliating countries imposed tariffs on less than $20 \%$ of the 2017 value of agricultural products imported from the US (column 3, Table 1). Note also the strong seasonal dimension of China, and to some extent India's imports from the U.S. (column 4). Sixty-eight percent of China's agricultural imports from the US targeted by retaliation are imported during the US's peak marketing months January-February and September-December. This seasonal dimension is most prevalent in bulk products (Table 1).

Retaliatory trade actions not only affect US agricultural exports directly but may also cause a reorientation of exports to non-retaliating countries (trade deflection) (Bown \& Crowley, 2007). Columns 9 and 10 (Table 1) depict nonretaliating rest-of-world (ROW) agricultural imports from the US of products targeted for retaliation in each destination market, and for bulk, consumer, and intermediate products collectively. In 2018, ROW imports from the US of products targeted by China increased $9 \%$ or $\$ 9.6$ billion compared to 2017 . However, ROW imports from the US of products targeted by Canada, Mexico, EU, Turkey, and India showed only slight increases, compared to 2017. Across BICO sector categories (Bulk, Consumer, and Intermediate), ROW imports from the US increased $\$ 4.1, \$ 1.3$, and $\$ 1.2$ billion, respectively, totaling \$6.6 billion.

Finally, Figure 1 plots the 2017 value of US product category exports subject to retaliation in 2018/2019. To ease exposition, we focus on 35 US products with nonzero exports to China, Canada, Mexico, the EU, Turkey, and India in 2017. US soybean and pork exports are represented on a separate scale. In total, nearly $\$ 30$ billion of the 2017 value of US agricultural exports were impacted by retaliatory trade measures in 2018 and 2019. The breadth of China's retaliation (shown in blue) is evident and accounts for nearly $80 \%$ of the value of US agricultural exports facing retaliation.

\section{ECONOMETRIC RESULTS}

The econometric results are organized in three subsections. Subsection one presents the direct effect of retaliation, overall, by retaliating country, and by BICO sector (Equation 1 and Equations 2-3 in the Supplementary Technical Appendix). Section two discusses within- and across-year heterogeneity of the direct effect of retaliation. Here, we condition the analysis on in- and out-of-season trade effects, trade dispute years 2018 versus 2019, and various inflection 


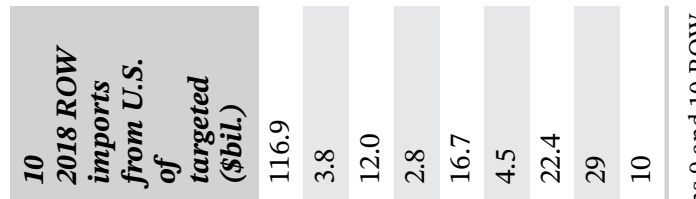

赵

。

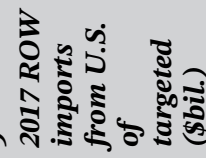

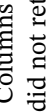

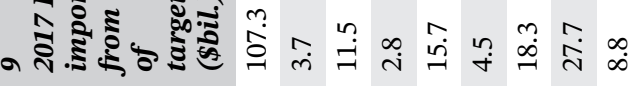

8

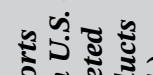

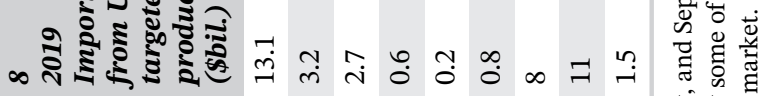

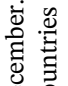

ठัญ

尚.

है

它

b

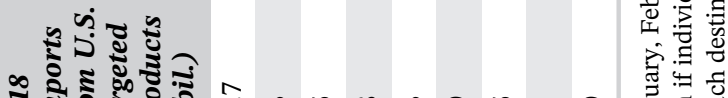

$\therefore$

要

ヘ

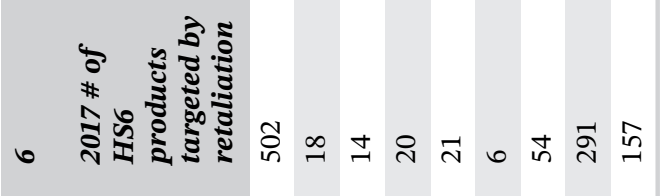

要

웅

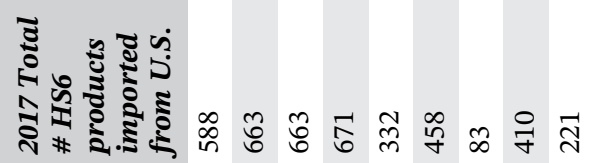

离

离若

ֻั)

n

这:

च्ठ

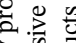

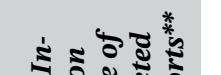

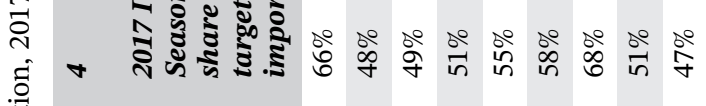

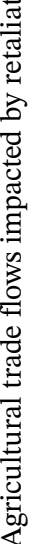

จุะี

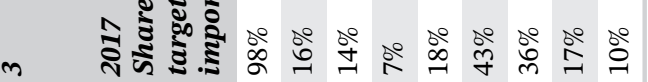

预

过

政

宽

递兽

要言焉

年<smiles>[CH]</smiles>

กั่

กิำ

v

要

䓈

농

ช

ग

卷声

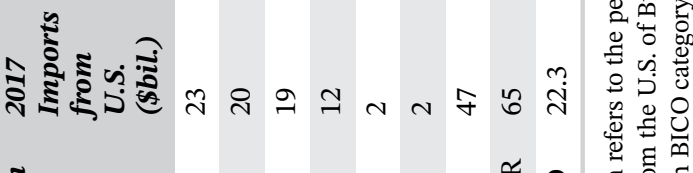

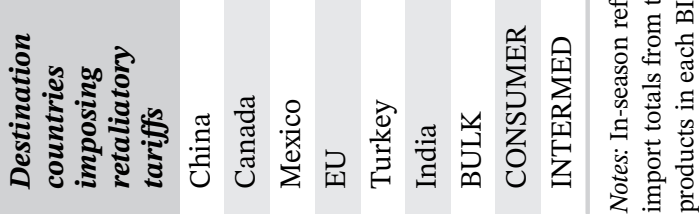




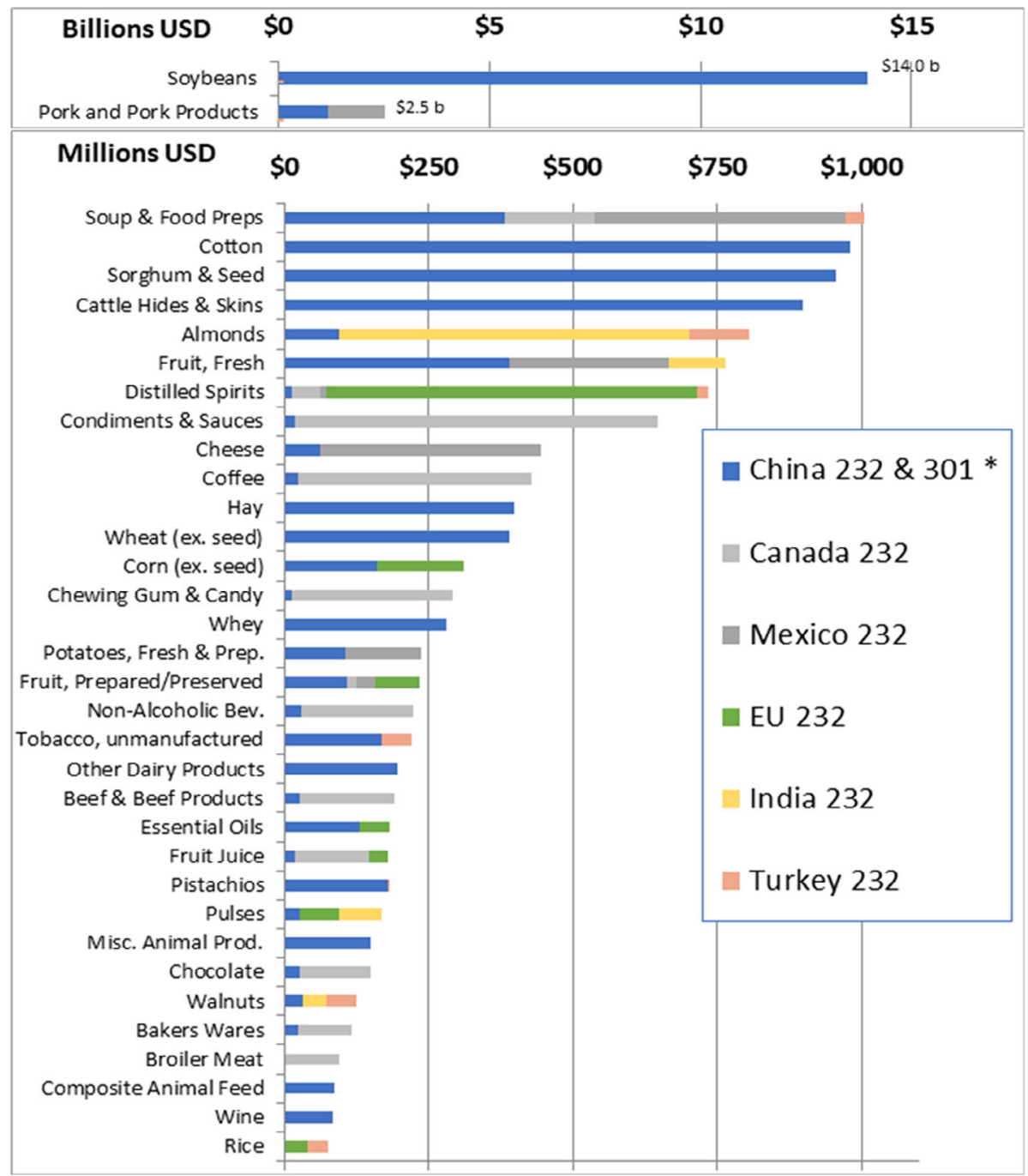

F I G U RE 12017 Value of U.S. agricultural exports subject to Section 232 and 301 retaliatory duties. Most products covered by China Section 232 tariffs are also subject to an additional Section 301 retaliatory duty. Canadian and Mexican retaliatory duties removed in May, 2019 [Color figure can be viewed at wileyonlinelibrary.com]

points within the overall U.S.-China trade conflict. Retaliatory trade impacts across disaggregated products categories are discussed in the final sub-section, where we compute counterfactual trade impacts for row crops, livestock, specialty crops, and other, and compare our results to USDA's trade damage estimates.

\section{Direct effect of retaliation}

To what extent did retaliation impact US agricultural exports? Table 2 presents the overall, country, and BICO sector estimation results. ${ }^{10}$ Overall, our findings suggest that retaliation 
against US agricultural exports resulted in a $46 \%$ to $49 \%$ decline in US monthly product exports, on average. ${ }^{11}$ Also noteworthy is the stability of this result across variations in the number of additional fixed effects included. Columns (2), (3), and (4) add importer-time, product-time, and month-time fixed effects, respectively. Using column (4) as our most demanding specification results in an average treatment effect of retaliation of $-48 \%((\exp (-0.66)-1) \times 100)$. Although not reported in Table 2, the results using exporters' reported exports produces an almost identical result with a retaliation coefficient of -0.61 implying a $46 \%$ reduction of U.S. product-month exports, on average.

Columns (5) through (8) decomposes the overall effect of retaliation by retaliating country. Importantly, the previous results mask a significant retaliation effect by China, and to a lesser extent the EU. Here the results suggest that US exports to China decreased by $56 \%$ to $76 \%$ (columns 5-8), on average. Using 2017 trade values prior to the trade dispute (Table 1), this effect translates into annualized estimated trade losses of $\$ 12.6-\$ 17.2$ billion in the China market alone. The direct trade losses represent the amount of US export sales to China that would have been expected without retaliatory tariffs.

Following China, retaliation by the Mexico also had a significant impact on imports from the US, with reductions of targeted products of $15 \%$ to $20 \%$ (columns $5-8$, Table 2 ). The model results suggest direct export losses of \$380-\$524 million with Mexico. Although smaller, the corresponding trade effects of retaliation by EU (\$327-\$382 million), Canada (\$98-\$257 million), India (\$30-\$222 million), and Turkey (\$64-\$132 million) were also significant. Relatively speaking, the larger China trade effect (in absolute value) is likely driven not only by higher retaliatory tariffs but also the role of non-tariff related trade actions such as China's August 5, 2019 announcement that its state-owned firms will stop purchasing US agricultural products. Adding up the total estimated retaliatory trade losses across destination markets amounts to $\$ 13.5-\$ 18.7$ billion on an annualized basis. With the exception of Canada and Mexico, most retaliatory tariffs that had been imposed are still in effect. Thus, the total accumulated losses likely exceed the aforementioned annualized estimates.

Columns (9) through (12) investigate the trade effect of retaliation by BICO sectors which groups products according to different stages of production (Bulk, Intermediate and Consumer-oriented (BICO)) (Appendix C). Decomposing retaliation across BICO sectors reveals an important finding: The trade effect of retaliation is driven to a large extent by retaliation on more homogeneous bulk products. Chaney (2008) shows succinctly that if goods are less substitutable, such as differentiated consumer-oriented products compared to bulk commodities, importing firms and consumers are willing to purchase foreign products at higher prices and thus trade barriers should have smaller impacts on trade flows. ${ }^{12}$ Our findings support Chaney's theoretical results: Retaliation reduced US bulk commodity exports by a striking $79 \%$, on average, followed by a $57 \%$ and $25 \%$ reduction of intermediate and consumer-oriented products, respectively (column (12)). In other words, product differentiation tends to dampen the impact of retaliatory tariffs. The estimated trade losses (column (12)) total $\$ 13.4$ billion for bulk commodities (derived from Table 1) representing $77 \%$ of total losses by value.

It is also important to note the more significant negative retaliation coefficients when we add country-time, product-time, and month-time fixed effects (Table 2). These additional timevarying fixed effects help control for other confounding factors specific to each country, HS6 product, or month. For example, in the fall of 2018, China faced an outbreak of African swine fever (ASF) unrelated to the trade dispute that affected its domestic pork supply (Nti et al., 2019). All else equal, a production shock of this magnitude will put upward pressure on 


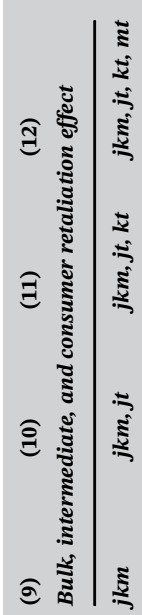

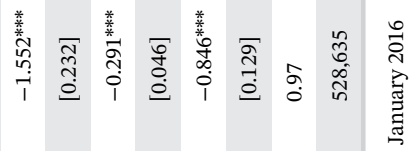

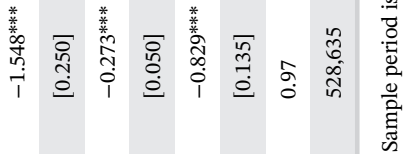

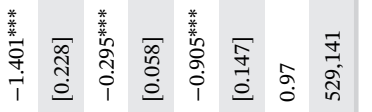

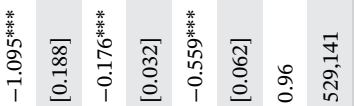

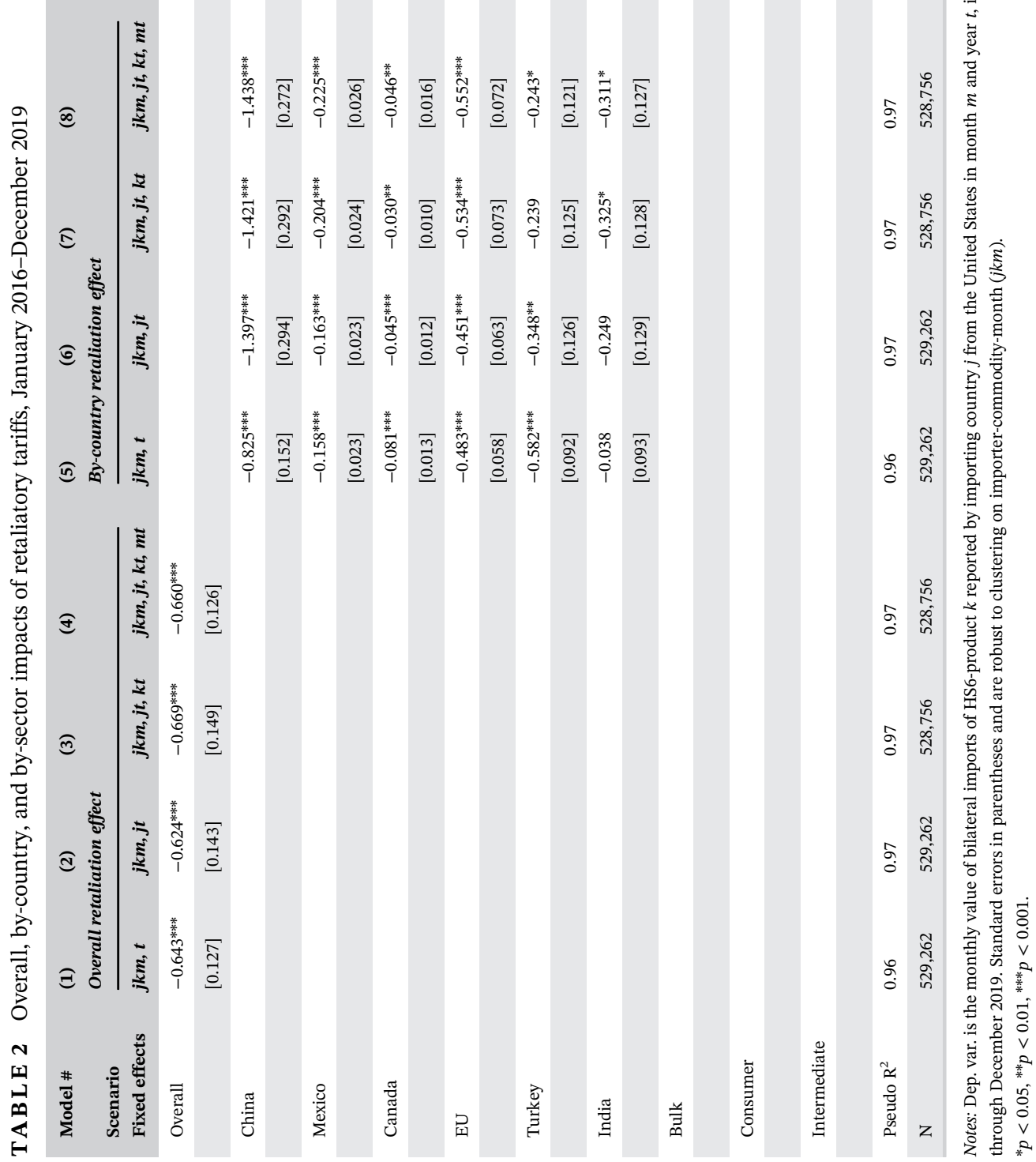


China's domestic pork prices. To maintain a stable supply, Chinese demand for imported pork from all countries will increase.

\section{Within-year seasonal effects, 2018 versus 2019, and "phases" of the trade dispute}

While the previous results underscored the negative trade effects of retaliation, monthly panel data allow us to examine several additional insights: (a) within-year "seasonal" differences; (b) retaliation in that occurred in 2018 compared to 2019; and (c) phases of the US-China trade dispute. The estimated trade effects are illustrated using Figure 2. The full set of econometric results from this analysis can be found in Appendix E.

We find several economically important and statistically significant within- and across-year effects of retaliation. First, the previously reported overall trade impact of $48 \%$ (Table 2, column (4)) is driven by a significantly higher $57 \%$ reduction of in-season imports (January, February, and September-December) from the US, compared to just a $26 \%$ reduction in out-of-season imports (March-August) (Figure 2, Overall). Testing the equality of the in- and out-of-season coefficients is easily rejected at conventional significance levels $\left(\mathrm{H}_{1}\right.$, Appendix $\left.\mathrm{E}\right)$. Second, the middle panel of Figure 2 illustrates that the overall in-season effect of retaliation is driven almost entirely by a large seasonal trade effect on bulk commodities with little to no seasonal effect on intermediate or consumer products. This presence (absence) of seasonality in bulk (consumer and intermediate) product trade is confirmed in hypothesis test $(\mathrm{s}) \mathrm{H}_{2}\left(\mathrm{H}_{3}-\mathrm{H}_{4}\right)$ (Appendix E). Retaliatory trade measures reduced US in-season bulk commodity trade by a notable $77 \%$, on average, compared to a 35\% reduction in out-of-season trade. Using 2017 trade values and the in-season share of bulk commodity exports (Table 1), our results suggest that retaliation led to in-season export losses of $\$ 8.9$ billion ( $\$ 17$ billion*68\% in-season share*-77\% estimated trade effect). Third, of the six countries that imposed retaliatory duties against US agriculture, only retaliation by China and Turkey produced significantly different seasonal trade effects (Appendix E, hypotheses tests $\mathrm{H}_{5}$ and $\mathrm{H}_{9}$ ). ${ }^{13}$

In the final graphic in Figure 2, we evaluate and test for differences between trade dispute years 2018 and 2019 (column (4) Appendix E). The results underscore the importance of 2018 and the initial phases of the trade conflict. For example, the average treatment effect of retaliation
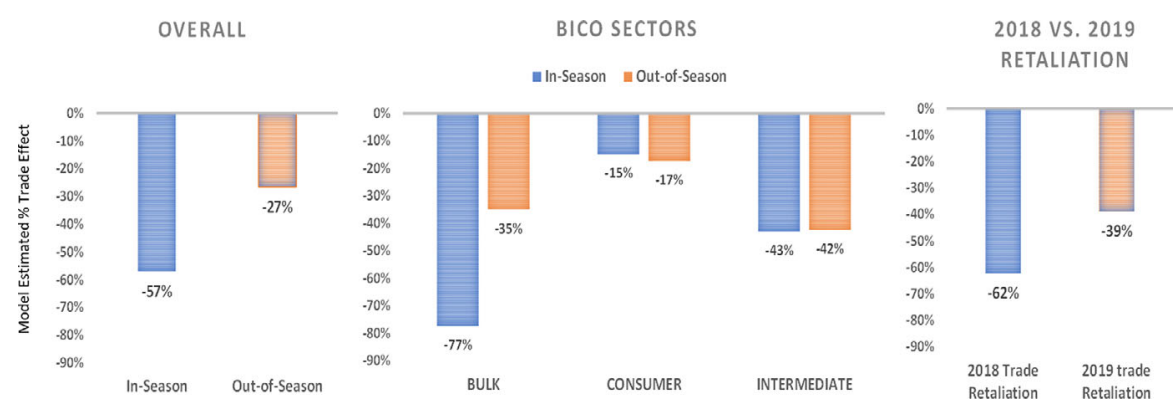

F I G U RE 2 Seasonality and 2018 versus 2019 trade retaliation. Percentage trade effects are based off model estimated coefficients reported in Appendix D. In-season months during the trade dispute are January, February, and September-December reflecting the peak export marketing period for some United States exports. Out-ofseason months during the trade dispute are March-August [Color figure can be viewed at wileyonlinelibrary.com] 
in 2018 reduced US exports by $62 \%$ compared to a reduction of $39 \%$ in 2019. Across BICO sectors and countries, testing the equality of the 2018 versus 2019 retaliation coefficients (column (4), $\mathrm{H}_{1^{-}}$ $\mathrm{H}_{9}$ in Appendix E) points to a significantly stronger trade impact of retaliatory tariffs in 2018 compared to 2019. ${ }^{14}$ Several reasons may explain this result. First, the magnitude of the initial 2018 tariff increases as a percentage of existing applied tariffs were larger at the onset of the trade dispute compared to subsequent tariff increases in 2019. For example, China increased its $3 \%$ tariff on US soybean exports by 25 percentage points in July of 2018, and its $12.5 \%$ tariff on many pork products increased 25 percentage points in April 2018 (Section 232) and by another 25 percentage points in July 2018 (Section 301) (Grant et al., 2019). Second, the magnitude of the Mexico and Canada retaliation coefficients in 2019 are roughly half those in 2018 (Appendix E), perhaps due to Canada and Mexico removing their Section 232 retaliatory tariffs in May of 2019 to facilitate ratification of the Unites States-Mexico-Canada Agreement (USMCA).

Finally, we consider various ebbs and flows of the US-China trade dispute by dividing it into five phases:

i. Phase 1-China's Section 232 retaliation covering the period April 2018-June 2018 and reflecting the earliest and more limited phase of the trade conflict;

ii. Phase 2-China's Section 301 retaliation covering the period July-December 2018 where trade relations between the two countries hit a low point and the trade conflict launched into a more comprehensive trade war;

iii. Phase 3-a "trade truce" period covering the period January-April 2019. The US and China exchange several goodwill gestures to facilitate trade discussions including some purchases of U.S. soybeans;

iv. Phase 4-trade discussions falter during May 2019-September 2019. US-China trade negotiations collapse, and trade tensions escalate with further increases in tariffs; and

v. Phase 5-Trade talks rekindle covering the period October-December 2019, as optimism for a potential US-China trade deal begin to surface and China reportedly begins making goodwill purchase gestures. ${ }^{15}$

Phases 2 and 4 (July-December 2018 and May-September 2019) can be characterized as trade dispute low points where negotiations deteriorated, and both countries threatened or imposed additional tariffs. Phases 3 and 5 are characterized as high points in the trade dispute because the US and China either agreed to halt further increases in tariffs or negotiations were progressing toward the US-China Phase One trade deal. In column (5) of Appendix E, we examine the degree to which the retaliatory trade effect varies with the phases of the US-China trade war. To briefly summarize, the results are only partially consistent with the above phases. Phase two resulted in the largest percentage reduction in US agricultural exports at 82\%, marking the most severe point of the trade war. Somewhat counterintuitively, however, the estimated trade impact became insignificant in the middle part of 2019 (Phase 4), despite trade talks faltering.

The asynchrony between estimated trade impacts and the phases discussed above is in part driven by the lag time between when export sales are transacted (i.e., China makes goodwill purchases) and the point at which shipments arrive in China, which can be several months later. Using USDA weekly net sales, the relationship becomes clearer. Figure 3 illustrates weekly US soybean net sales to China. The blue line represents shipments since 2018; the orange line shows the historical averages over the 2014-2017 period for comparison. While shipments of soybeans typically ramp up during the fall months following harvest, sales for 


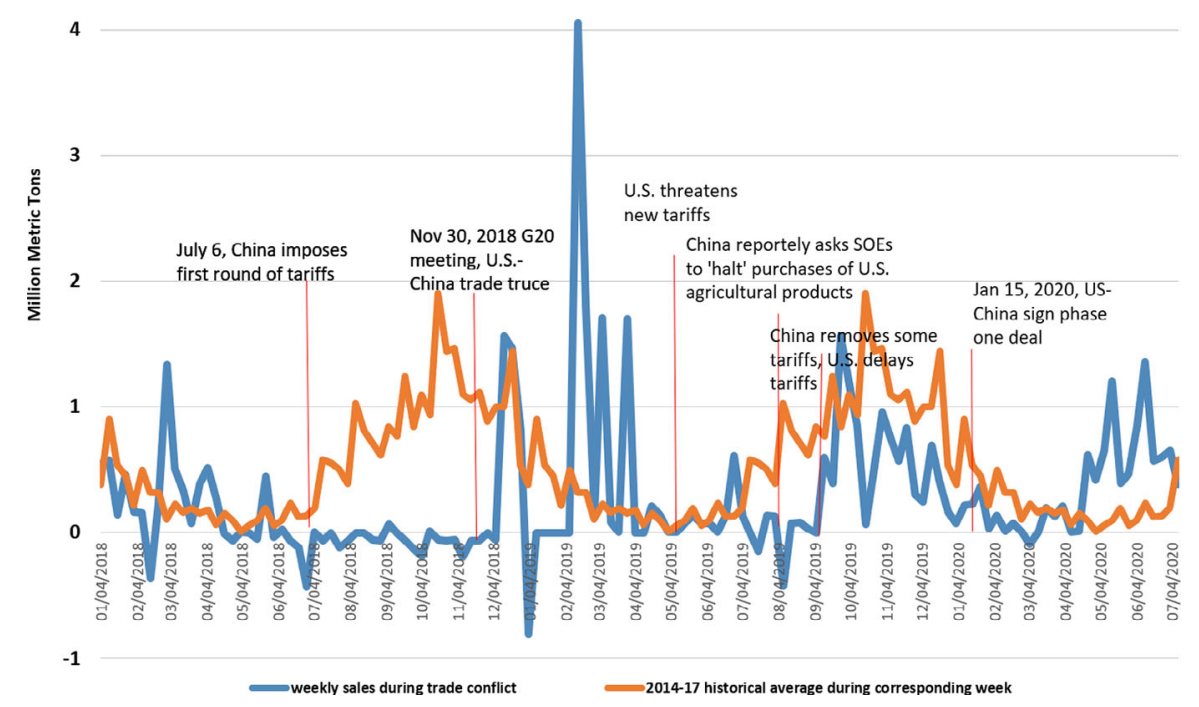

F I G U RE 3 Phases of the US-China trade dispute and U.S. soybean weekly net sales to China. Weekly net sales is the total resulting new export sales (contracted) minus cancellations for current and new marketing year. USDA-FAS weekly sales available at: https://apps.fas.usda.gov/export-sales/esrd1.html [Color figure can be viewed at wileyonlinelibrary.com]

future delivery with China in 2018 fell far below historical averages. It wasn't until phase 3 and the trade truce that soybean sales contracts increased (January-February 2019), a period in which historically fewer sales are contracted. When trade negotiations faltered (Phase 4) in the summer of 2019, limited new soybean sales were contracted. Sales contracts resumed later in the fall in tandem with trade talks rekindling (Phase 5).

\section{A closer look at retaliation on US product-line exports and USDA trade damage estimates}

In response to retaliatory tariffs, the US government developed and implemented several programs to assist farmers suffering from trade disruptions due to the retaliatory tariffs. In July 2018 , the USDA announced the first trade aid program of up to $\$ 12$ billion in funds. In May 2019 , the USDA announced a second trade aid program to provide up to $\$ 16$ billion in additional funds. The USDA used an Armington-based partial equilibrium model to project the expected level of direct trade loses for the targeted commodities, with and without the tariffs in place, and differenced them (USDA, 2019). The USDA assessment took place ex-ante-that is, before the tariffs were put in place at a time where ex-post data could not be observed.

How do our ex-post econometric estimates compare with the USDA's ex-ante trade aid figures? First, as reported earlier, total annualized export losses due to retaliatory tariffs amounted to $\$ 13.5$ to $\$ 18.7$ billion. This range is roughly in line with the total size of USDA's, 2019 trade aid program of $\$ 16$ billion. The size of the 2018 program ( $\$ 12$ billion) falls below this range; however, the initial USDA program reflected a smaller scale of tariffs that had been in effect at the time of program operation (USDA, 2019). ${ }^{16}$

To unpack the aggregate differences, Table 3 presents a side-by-side comparison of the econometrically estimated counterfactual direct trade losses at the sub-sector level against the 
value of USDA's trade aid. The product-level estimations are performed separately, (product-byproduct), to more effectively control for unobserved effects specific to each subsector. ${ }^{17}$ The counterfactual value of US direct trade losses is based on the coefficient estimates reported in Appendix F, and projected off a 2017 preretaliatory base period. The direct export sales losses for products impacted by multiple markets are aggregated by summation across these markets.

Note the resulting totals do not add up to the aggregate $\$ 13.5$ to $\$ 18.7$ billion totals reported earlier for two reasons. First, several product level estimates could not be matched to USDA trade damage estimates due to differences in product aggregation on which estimations were performed, and cases in which comparable estimates were not available. For consistency, Table 3 organizes the subsector results in a structure that is comparable to USDA's sector groupings employed in the Market Facilitation Program (MFP) and the Food Purchase and Distribution Program (FPDP): ${ }^{18}$ Nonspecialty Row Crops, Livestock, and Specialty products. ${ }^{19}$ Second, because the level of precision is naturally less when estimated at the disaggregated product level, we only report selected estimates in Table 3 that were statistically and economically significant at the product level.

China's retaliation against US soybean exports resulted in the largest and most significant direct trade losses. Soybean producers were also the recipients of the largest trade assistance payments by USDA. Using a 2017 preretaliation base year, we find US soybean exports to China were reduced by an average of $\$ 10.7$ billion annually. In comparison, USDA estimated slightly lower trade losses of $\$ 7.3$ and $\$ 8.5$ billion for the 2018 and 2019 programs, respectively. Retaliation against US pork reduced exports by over $\$ 1$ billion annually in direct export sales: $\$ 777$ million in losses to China and \$306 million to Mexico. This is largely in line with USDA's 2018 and 2019 estimates of \$1.14 and \$1.09 billion, respectively. The econometric estimates for coarse grains (including sorghum) were higher than USDA estimates for both years of the programs. Sorghum trade had virtually ceased during the trade war, whereas USDA's model predicted some level of trade to continue. Estimates for other cereals (wheat and rice) were consistent with USDA's estimates for the 2018 trade aid program; however, the econometric estimates are lower than USDA's, 2019 estimates. The econometric estimates for cotton were also in line with the USDA's 2018 estimates; however, the USDA forecasted a much higher cotton trade damage for their 2019 program.

Some overall sector-level comparisons are also worth highlighting in Table 3. First, both the econometric and USDA trade damage estimates find much higher losses for the nonspecialty/ row crops sector relative to livestock/dairy and specialty crops, with counterfactually estimated trade losses totaling $\$ 12.8$ billion. USDA's 2018 estimates were a smaller $\$ 8.7$ billion, whereas their 2019 estimates are closer at $\$ 14$ billion. Second, the econometric and USDA estimates generally agree for livestock, dairy, meat products, fresh fruit and vegetables, and nuts.

The close relationship between USDA's ex-ante and the ex-post econometric trade damage estimates for 2018 and 2019 is illustrated in Figure 4, using a $45^{\circ}$ line scatterplot. Combinations of USDA and the econometric trade loss estimates that lie above (below) the $45^{\circ}$ line represent higher (lower) ex-ante USDA program estimates relative to the ex-post econometric estimates. As can be seen, USDA's 2018 program estimates tended to fall slightly below the $45^{\circ}$ line indicating the program slightly underestimated trade losses compared to the ex-post counterfactually estimated trade losses. The trade-weighted average difference between the econometric and USDA's estimates was $-25.9 \%$ in 2018. In contrast, the 2019 USDA trade damage estimates were slightly above the $45^{\circ}$ line, with a weighted average difference of $+10.4 \%$ higher than the ex-post econometric estimates. Pearson's correlation coefficient between the two estimates is 0.99 for the 2018 , and 0.97 for the 2019 program. 


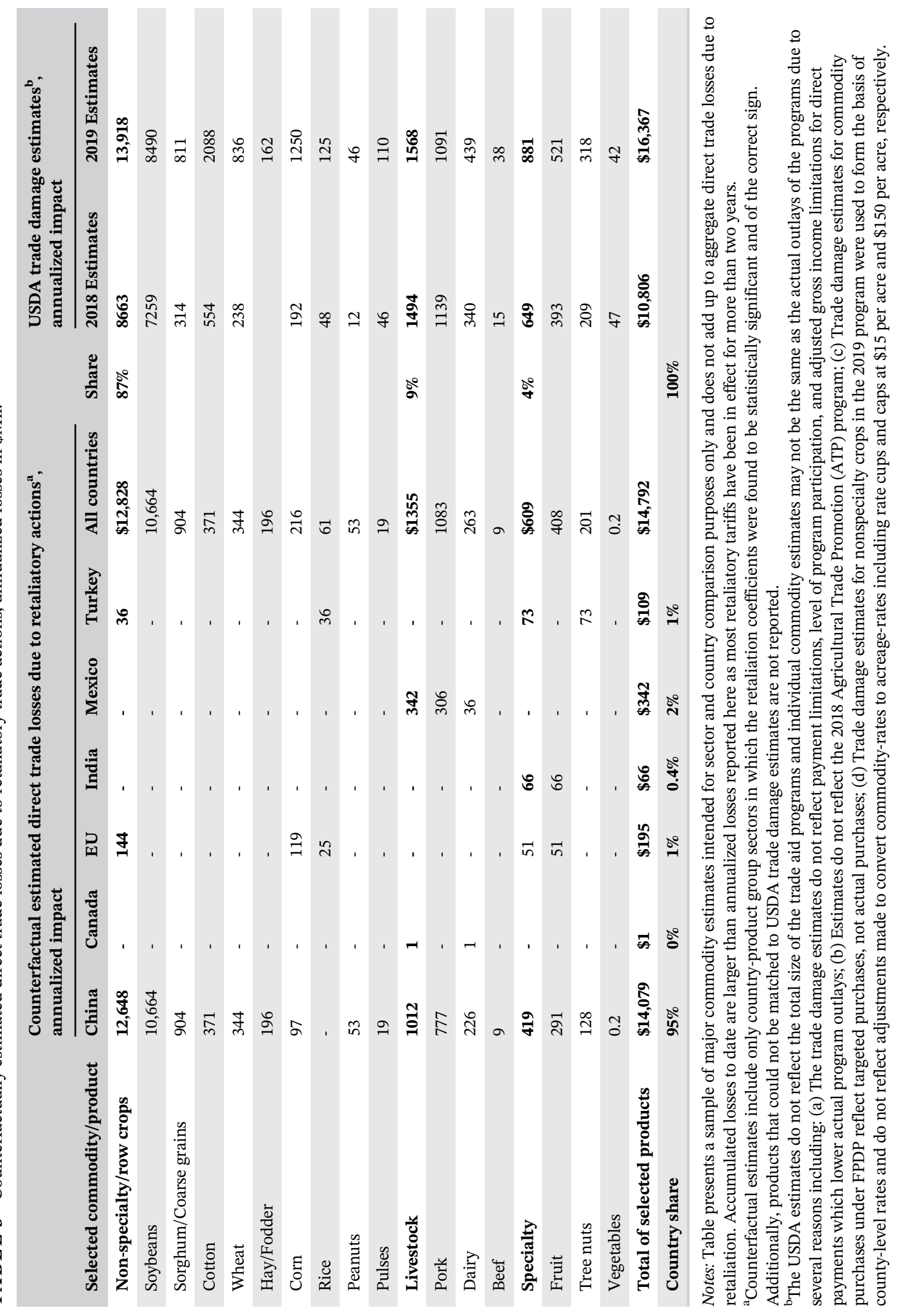




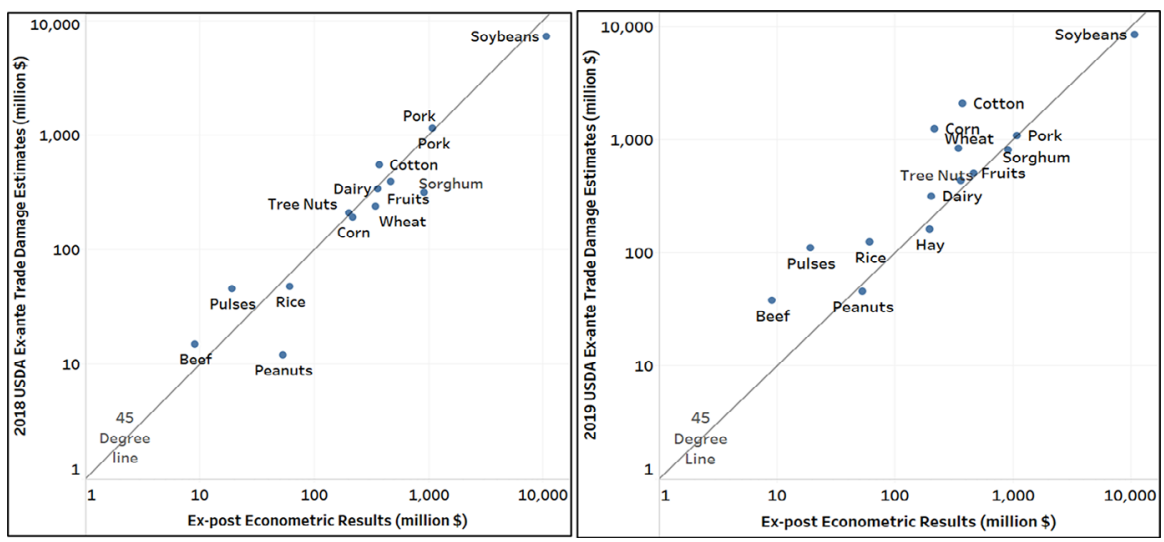

F I G U RE 4 Counterfactual econometric results versus USDA's 2018 and 2019 trade damage estimates. $45^{\circ}$ line denotes a 1:1 correspondence between USDA's ex-ante trade damage estimates and the ex-post econometric estimates. Combinations above (below) the $45^{\circ}$ line represent higher (lower) ex-ante USDA damage estimates relative to the ex-post econometric estimates. $\mathrm{X}$ and $\mathrm{Y}$ axes presented in logarithm scale [Color figure can be viewed at wileyonlinelibrary.com]

Third, from a policy perspective, it is interesting to disentangle the product and country shares of counterfactually estimated trade losses in Table 3. Across commodities, row crops accounted for $87 \%$, or $\$ 12.8$ billion of the $\$ 14.8$ billion in total trade losses. Row crops are followed by livestock, with a share of $9 \%$ or $\$ 1.4$ billion in trade losses; and $4 \%$ (\$609 million) in specialty crop losses. At the country level, the implication is clear: $95 \%$ of the direct trade losses are due to retaliation by China. Mexico retaliation is a distant second at $\$ 342$ million across all products, representing just a $2 \%$ share in total U.S. trade losses.

Figure 5 illustrates the relationship between the estimated trade effects, 2017 US export values, and US export market shares for each country-product using a bubble graph. Model estimated percentage trade effects of retaliation (presented in Appendix F), are plotted on the vertical axis against the share of US exports of each product in retaliating market $j$ on the horizontal axis. The diameter of the bubble reflects the average value of 2017 US exports preceding the trade dispute. To ease exposition, 31 country-product bubbles are included.

Retaliation by China on coarse grains, ethanol, DDGs, and wheat, and EU retaliation on fruit and vegetable juices (FVjuice) and corn represented the largest estimated trade effects near or exceeding an $80 \%$ reduction in imports from the US. Coarse grains is located furthest to the right along the horizontal axis indicating a large dependence on exports to the Chinese market (over $80 \%$ ) in 2017. However, retaliation by China on coarse grains, as well as ethanol, DDGs, and wheat are represented by smaller bubble diameters (2017 export values). The largest 2017 bubble diameters are soybean exports to China (\$14 billion), and alcohol exports to the EU ( $\$ 1.5$ billion). Soybeans, however, is the only product that has a very large bubble diameter and is located in the lower right-hand quadrant of Figure 5. Within North America, retaliation by Mexico and Canada impacted US agricultural exports to a much smaller extent than was generally found in China, the EU, Turkey, and India's retaliation on fresh fruit.

As a final note, we also examined the potential for trade deflection of US agricultural exports, or the extent to which exports targeted by retaliation are reoriented to nonretaliating destination markets (i.e., US exports to Japan). We find limited evidence of US exports increasing to alternative nonretaliating markets. Trade deflection was positive and significant in only 


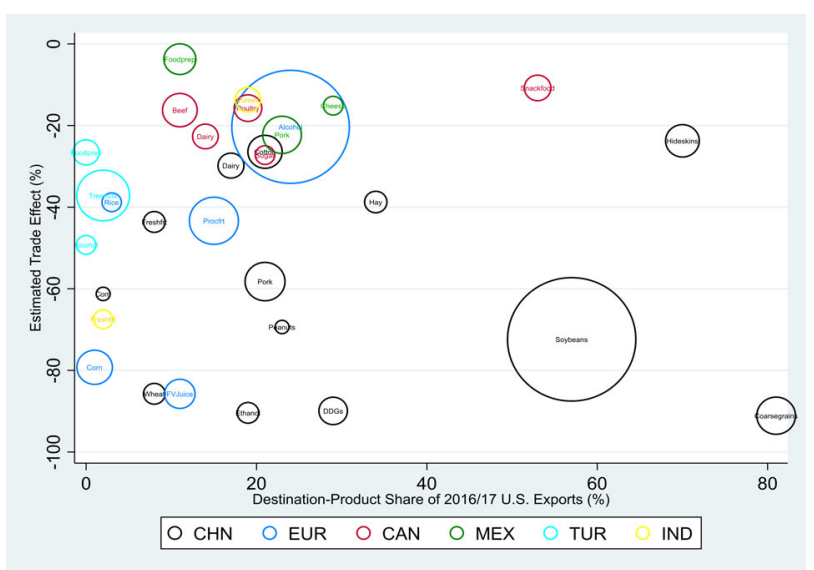

FI G U RE 5 BICO product effects of retaliation and 2016/2017 U.S. export shares and export values. Figure encompasses three dimensions: (a) location of the bubble north and south depicts the model estimated trade effect of retaliation on U.S. exports, (b) location of the bubble east and west depicts the country-product U.S. export share in the pre-retaliation period (2017), and (c) diameter of the bubble indicates the total value of U.S. exports to each destination-product. Colors are used to delineate retaliatory destination markets labeled as follows: CHN, EUR, CAN, MEX, TUR, IND denoting, respectively, China, EU-28 members, Canada, Mexico, Turkey, and India [Color figure can be viewed at wileyonlinelibrary.com]

10 out of 54 product-level estimations, with the largest estimates occurring for sorghum and corn (China retaliation), apples (India retaliation) and limited US soybean exports (China retaliation). The limited trade deflection suggests that trade frictions and fixed costs associated with the establishment of non-traditional supply chains in alternative markets are high. Put differently, bilateral trade disruptions do not lead to a simple or relatively low-cost reshuffling of commodity trade, at least in the short run. More likely, retaliatory trade actions disrupt trade that is not easily recovered, leading to economic impacts that are destructive and costly.

\section{CONCLUSIONS}

Economists often extol the virtues of freer trade because of the real income effects associated with protectionism as consumers lose more than producers gain leading to deadweight losses (Balassa, 1965; Irwin, 2010; Josling et al., 1996). Using a model of bilateral trade to retaliating and nonretaliating markets, this article established new insights about the effect of retaliation on US agricultural exports. Summarizing the impacts of the trade war is challenging because other market variables are impacted when retaliatory trade measures are imposed, including domestic price and basis movements, the cost of storing commodities, perishability, quality considerations when markets are lost, and the (fixed) costs of stopping and restarting trade relationships (Peterson et al., 2018). Perhaps most importantly, there is the unknown, longerterm potential cost of US agricultural exports not regaining its once sizeable position in these markets. Such an outcome was also seen when the US began refining a large portion of its corn crop into ethanol in 2007. Since then, the US has lost export market share to other countries that has yet to be regained, even as demand for corn-based ethanol has flattened since 2016. 
Several findings, however, are worth summarizing. First, retaliatory trade actions on US agricultural exports were significant. Overall, US agriculture experienced annualized direct trade losses of $\$ 13.5$ to $\$ 18.7$ billion. Second, while trade retaliation was broad in scope, trade impacts at the product level are heterogeneous. Retaliation by China was the most significant, both in terms of scale with roughly $\$ 17$ billion in annualized US trade losses accounting for $95 \%$ of aggregate retaliation by all countries, and severity, with trade reductions of over $75 \%$. Across sectors, however, we find that the retaliatory trade effect is moderated as the degree of product differentiation increases. Within bulk commodities, soybean trade losses were the steepest at $\$ 10.7$ billion, followed by $\$ 0.9$ billion for coarse grains, and $\$ 0.6$ billion for fruits, vegetables, and tree nuts. The largest consumer-oriented product impacted by trade retaliation was pork with US exports declining by an estimated $\$ 1.1$ billion. Finally, we find that the ex-post econometrically estimated trade losses were largely consistent with USDA's trade damage estimates across program commodities.

On January 15, 2020, the United States and China signed the Phase One trade deal aimed at addressing structural barriers and further opening China's market to US agricultural products. As part of the Phase One agreement, China committed to purchasing an average of $\$ 40$ billion of agricultural goods, including seafood, annually from the US over calendar years 2020 and 2021, twice the amount of pretrade war levels. Achieving these targets will involve making up a large shortfall caused by the past two years of retaliatory tariffs. Whether US agricultural exports can recover lost market share in China is likely to be the subject of a considerable amount of future research.

\section{ACKNOWLEDGEMENTS}

The authors wish to thank Ian Sheldon, Wyatt Thompson, Daniel Petrolia (AEPP Editor) and participants at the 2019 Annual Meeting of the International Agricultural Trade Research Consortium in Washington D.C., and the 2020 virtual Annual Meeting of the American Agricultural and Applied Economics Association for helpful suggestions. The findings and conclusions in this article are those of the authors and do represent any official U.S. Department of Agriculture or U.S. government determination or policy. Grant and Emlinger are grateful for funding provided by the Office of the Chief Economist under Cooperative Agreement No. 58-0111-19-013. C.X. gratefully acknowledges financial support by the National Science Foundation of China (Project Nos. 71903090 and 71934005), and the Priority Academic Program Development of Jiangsu Higher Education Institutions (PAPD).

\section{ENDNOTES}

${ }^{1}$ Sixty-one percent of India's retaliation, nearly $20 \%$ of Turkey's, 33\% of EU retaliation, $20 \%$ of Canada's, and $79 \%$ of Mexico's retaliation targeted US agri-food products using 2017 agricultural and nonagricultural import values. Sixty-eight percent of China's initial Section 232 retaliation and 22\% of its Section 301 retaliation impacted US agri-food products.

${ }^{2}$ Fajgelbaum et al. (2020) and Flaaen et al. (2019) find a similar, if not surprising result that higher U.S. tariffs were fully passed through to import prices.

${ }^{3}$ Head and Mayer (2014), Peterson et al. (2013), and Baldwin and Taglioni (2006) provide formal derivations of the gravity equation at the product line. The gravity model used here is not fully structural as in Anderson and Yotov (2016) and Yotov et al. (2016) in conditional or full endowment general equilibrium (GE). By design, the full GE gravity setup requires intranational trade flows (i.e., trade with self) which is nearly impossible to obtain across months. Thus, our results are consistent with best practices to estimate partial direct effects also advocated by Yotov et al. (2016). 
${ }^{4}$ For example, Chinese pork imports from all sources tend to spike in January and February each year as part of the Chinese New Year; fresh fruit and vegetable exports to Canada tend to be higher in spring and fall months coinciding with peak Florida and California marketing periods, respectively; and soybeans, coarse grains, tree nuts and other commodity exports to China, Turkey and other retaliating markets increase significantly during the US's peak marketing period (September through February).

${ }^{5}$ See https://www.bloomberg.com/news/articles/2019-08-05/china-asked-state-buyers-to-halt-u-s-agricultureimports

${ }^{6}$ Trade Data Monitor data are available by subscription at https://tradedatamonitor.com/.

${ }^{7}$ We use the HS2012 revision of product codes so that we can include 2016 in the sample period giving us two years prior to and during the trade dispute. Several product codes changed between HS2012 and HS2017. These were reconciled using the UN Comtrade's concordance tables among various HS revisions (see https://unstats. un.org/unsd/trade/classifications/correspondence-tables.asp). The US Department of Agriculture provides a concordance between BICO product categories and HS6 product codes (https://apps.fas.usda.gov/gats/ default.aspx).

${ }^{8}$ Retaliation against agricultural products was retrieved from official national sources. China: http://www. mofcom.gov.cn/article/b/ (Ministry of Commerce); EU: http://trade.ec.europa.eu/doclib/press/index.cfm? action=search (European Commission); Canada: https://www.canada.ca/en/department-finance/programs/ international-trade-finance-policy/measures-steel-aluminum-businesses/countermeasures-response-

unjustified-tariffs-canadian-steel-aluminum-products.html(Department of Finance); Mexico: https://www.gob. $\mathrm{mx} / \mathrm{se}$ 571 (Ministry of Commerce); India: https://www.cbic.gov.in/Customs-Notifications (Ministry of Finance);Turkey: https://www.resmigazete.gov.tr/\# (Executive Affairs Law and Legislative Directorate of the Turkish Presidential Palace)

${ }^{9}$ To save space we exclude product codes affected by China's retaliation in Appendix D. While China's retaliation was imposed in several waves, almost all agricultural product codes were eventually targeted for retaliation.

${ }^{10}$ Fixing the sample to include only one exporting country, the US helps with estimation time and convergence by limiting the dimensionality of the within country-pair-product-month fixed effects from ijkm in Equation (1) to $j k m$ (with $i=$ United States). The results are virtually identical if we use the full sample of observations $(i j k m)$ over time.

${ }^{11}$ The calculation of percentage trade flow effects in PPML models with dummy variables (Equation (1)) is identical to those of logarithmic gravity equations: $\left(\exp \left(\gamma_{1}\right)-1\right)^{*} 100$.

${ }^{12}$ Chaney (2008) shows that the opposite is true for the extensive (i.e., entry) margin of trade.

${ }^{13}$ This is not to say that China and Turkey systematically imposed more restrictive tariffs or import restrictions on US products in-season. Rather, the results in Appendix E illustrate the important point that more significant export losses compared to the model's predicted trade flows tended to occur on in-season bulk commodity trade.

${ }^{14}$ India did not impose retaliatory duties until June of 2019. Thus, it is not possible to perform the 2018 versus 2019 comparison for this country.

${ }^{15}$ See https://www.usnews.com/news/business/articles/2019-09-12/chinese-buyers-asking-about-us-soy-porkbefore-trade-talks\#: :text=In\%20Beijing\%2C\%20China's\%20Commerce\%20Ministry,at\%20ending\%20the\% 20tariff $\% 20$ war.

${ }^{16}$ The size of these programs is also comparable in magnitude to the econometric estimates of Carter and Steinbach (2020). Other studies have compared the size of USDA trade damage estimates to price-based impacts. These estimates generally find lower losses than estimates based on direct trade losses (including USDA's estimates) converted into per unit terms. Janzen and Hendricks (2020) find that various price impacts estimated due to retaliatory actions were lower than USDA's MFP commodity rates for major commodities. Adjemian, Smith et al. (2019) found that the retaliatory tariffs effects on soybean prices were also lower than the soybean MFP commodity rate. 
${ }^{17}$ For instance, time varying fixed effects (jt, it) are only useful to control for unobservable macroeconomic shocks that are uniform across products. Alternatively, time-varying importer-product fixed effects (jkt, ikt) can control for unobservable product level effects. However, such an approach is computational demanding, and the results do not lead to new insights beyond what can be achieved through estimations performed separately on individual products.

${ }^{18}$ The 2018 (2019) program included a separate Agricultural Trade Promotion (ATP) program in which \$200 (\$100) million was made available to assist US agricultural exporters in identifying and accessing new foreign markets.

19 This drops the estimates for many processed products, alcohol beverages, tobacco, and other commodities that were impacted by retaliatory tariffs but not included as part of USDA's MFP.

\section{REFERENCES}

Adjemian, Michael K., Shawn Arita, Vince Breneman, Rob Johansson, and Ryan Williams. 2019. "Tariff Retaliation Weakened the U.S. Soybean Basis" Choices, Quarter 4. https://www.choicesmagazine.org/UserFiles/ file/cmsarticle_722.pdf. Accessed December 19, 2020.

Adjemian, Michael K., Aaron Smith, and Wendi He. 2019. "Estimating the Market Effect of a Trade War: The Case of Soybean Tariffs." Paper presented at the 2019 Agricultural and Applied Economics Association Annual Meeting, Atlanta, Georgia, July 21-23.

Amiti, Mary, Stephen J. Redding, and David Weinstein. 2019.“"The Impact of the 2018 Trade War on US Prices and Welfare."Journal of Economic Perspectives 33(4): 187-210.

Amiti, Mary, Stephen J. Redding, and David Weinstein. 2020."Who's Paying for the US Tariffs? A Longer-Term Perspective."AEA Papers and Proceedings 2020(110): 541-546.

Anderson, James E., and Yoto V. Yotov. 2016."Terms of Trade and Global Efficiency Effects of Free Trade Agreements."Journal of International Economics 99 (March): 279-298.

Autor, David H., David Dorn, and Gordon H. Hanson. 2016.“The China Shock: Learning from Labor-Market Adjustent to Large Changes in Trade."Annual Review of Economics 8 (October): 205-240.

Balassa, Bela. 1965."Tariff Protection in Industrialized Countries.”Journal of Political Economy 73(6): 573-594.

Baldwin, Richard, and Daria Taglioni. 2006. "Gravity for Dummies and Dummies for Gravity Equations." Working Paper no. 12516, National Bureau of Economic Research.

Baldwin, Richard. 2016."The World Trade Organization and the Future of Multilateralism.”Journal of Economic Perspectives 30(1): 95-116.

Bown, Chad P. 2018. "Trump's Trade War Timeline: An Up-to-Date Guide." Trade and Investment Policy Watch (blog), Peterson Institute for International Economics (April 19, 2018). https://www.piie.com/blogs/tradeinvestment-policy-watch/trump-trade-war-china-date-guide. Accessed December 19, 2020.

Bown, Chad P. 2019. "US-China Trade War: The Guns of August." Trade and Investment Policy Watch (blog), Peterson Institute for International Economics (September 20). https://www.piie.com/blogs/trade-andinvestment-policy-watch/us-china-trade-war-guns-august. Accessed December 19, 2020.

Bown, Chad P., and Meredith A. Crowley. 2007.“Trade Deflection and Trade Depression.”Journal of International Economics 72(1): 176-201.

Bown, Chad P., and Douglas Irwin. 2018. "What Might a Trump Withdrawal from the World Trade Organization Mean for US Tariffs?" Policy Brief PB18-23. Washington, DC: Peterson Institute for International Economics.

Carter, Colin A., and Sandro Steinbach. 2020. "The Impact of Retaliatory Tariffs on Agricultural and Food Trade.” Working Paper no. 27147, National Bureau of Economic Research.

Cavallo, Alberto, Gita Gopinath, Brent Neiman, and Jenny Tang. 2019. "Tariff Passthrough at the Border and at the Store: Evidence from US Trade Policy.” Working Paper no. 26396, National Bureau of Economic Research.

Chaney, Thomas. 2008."Distorted Gravity: The Intensive and Extensive Margins of International Trade."American Economic Review 98(4): 1707-1721.

Crowley, Meredith A. 2019. Trade War: The Clash of Economic Systems Threatening Global Prosperity. London: CEPR Press. 
Fajgelbaum, Pablo, Pinelopi Goldberg, Patrick J. Kennedy, and Amit K. Khandelwal. 2020."The Return to Protectionism.'Quarterly Journal of Economics 135(1): 1-55.

Flaaen, Aaron B., Ali Hortacsu, and Felix Tintelnot. 2019. "The Production Relocation and Price Effects of U.S. Trade Policy: The Case of Washing Machines." Working Paper no. 25767, National Bureau of Economic Research.

Grant, Jason H., and Shawn Arita. 2017. "Sanitary and Phyto-Sanitary Measures: Assessment, Measurement, and Impact." Commissioned Paper No. 21, International Agricultural Trade Research Consortium.

Grant, Jason H., Shawn Arita, Charlotte Emlinger, Sharon Sydow, and Mary Marchant. 2019. "The 2018-2019 Trade Conflict: A One Year Assessment and Impacts on U.S. Agricultural Exports.” Choices (Quarter 4). https://www.choicesmagazine.org/choices-magazine/themearticles/the-economic-impacts-of-traderetaliation-on-us-agriculture-aone-year-review/the-20182019-trade-conflict-a-one-year-assessmentandimpacts-on-us-agricultural-exports

Grant, Jason H., and Kathryn A. Boys. 2012.“Agricultural Trade and the GATT/WTO: Does Membership Make a Difference?”American Journal of Agricultural Economics 94(1): 1-24.

Grant, Jason H., and Sharon Sydow. 2019. "The Economic Impacts of Trade Retaliation on U.S. Agriculture: A One-Year Review." Choices, Quarter 4. https://www.choicesmagazine.org/choices-magazine/theme-articles/ the-economic-impacts-of-trade-retaliation-on-us-agriculture-a-one-year-review/the-economic-impacts-of-traderetaliation-on-us-agriculture-a-one-year-review. Accessed December 19, 2020.

Head, Keith, and Thierry Mayer. 2014. “Gravity Equations: Workhorse, Toolkit, and Cookbook," In Handbook of International Economics, Vol 4, ed. Gita Gopinath, Elhanan Helpman, and Kenneth Rogoff, 131-195. Amsterdam, North Holland: Elsevier.

Hitchner, Joanna, Keith Menzie, and Seth Meyer. 2019. "Tariff Impacts on Global Soybean Trade Patterns and U.S. Planting Decisions." Choices, Quarter 4. http://www.choicesmagazine.org/choices-magazine/themearticles/the-economic-impacts-of-trade-retaliation-on-us-agriculture-a-one-year-review/tariff-impacts-on-globalsoybean-trade-patterns-and-us-planting-decisions. Accessed December 19, 2020.

Irwin, Douglas A. 2010."Trade Restrictiveness and Deadweight Losses from US Tariffs."American Economic Journal: Economic Policy 2(3): 111-133.

Janzen, Joseph P., and Nathan P. Hendricks. 2020.“Are Farmers Made Whole by Trade Aid?”Applied Economic Perspectives and Policy 42(2): 205-226.

Josling, Timothy E., Stefan Tangermann, and Thorald K. Warley. 1996. Agriculture in the GATT. New York: St. Martin's Press.

Marchant, Mary A., and H. Holly Wang. 2018. "Theme Overview: U.S.-China Trade Dispute and Potential Impacts on Agriculture." Choices, Quarter 2.

Muhammad, Andrew, S. A. Smith, and Stephen MacDonald. 2019. "How Has the Trade Dispute Affected the U.S. Cotton Sector?" Choices Quarter 4. http://www.choicesmagazine.org/choices-magazine/theme-articles/ the-economic-impacts-of-trade-retaliation-on-us-agriculture-a-one-year-review/how-has-the-trade-disputeaffected-the-us-cotton-sector. Accessed December 19, 2020.

Ning, Xin., and Jason H. Grant. 2019. "New Estimates of the Ad-Valorem Equivalent of SPS Measures: Evidence for Selected Case-Studies and Specific Trade Concerns.” Research Report, Center for Agricultural Trade. Report No. CAT-2019-10.

Nti, Frank K., Lindsay Kuberka, and Keithly Jones. 2019. "Impact of Retaliatory Tariffs on the U.S. Pork Sector." Choices, Quarter 4. http://www.choicesmagazine.org/choices-magazine/theme-articles/the-economic-impactsof-trade-retaliation-on-us-agriculture-a-one-year-review/impact-of-retaliatory-tariffs-on-the-us-pork-sector. Accessed December 19, 2020.

Orden, David. 2020."Multilateral Rules for Food and Agricultural Trade," In Current Issues in Global Agricultural and Trade Policy: A Tribute to the Work of Timothy Josling, ed. David Blandford and Stefan Tangermann. London: World Scientific Publishing Co. Forthcoming.

Peterson, Everett B., Jason H. Grant, Donna Roberts, and Vuko Karov. 2013."Evaluating the Trade Restrictiveness of Phytosanitary Measures on U.S. Fresh Fruit and Vegetable Imports.”American Journal of Agricultural Economics 95(4): 842-858.

Peterson, Everett B., Jason H. Grant, and Jeta Rudi-Polloshka. 2018."Survival of the Fittest: Export Duration and Failure and the Fresh Fruit and Vegetable Market."American Journal of Agricultural Economics 100(1): 23-45. 
Regmi, Anita. 2019. "Retaliatory Tariffs and U.S. Agriculture.” Congressional Research Report No. R45903, Congressional Research Service.

Rodrik, Dani, and Rafael Di Tella. 2020."Labour Market Shocks and the Demand for Trade Protection: Evidence from Online Surveys."Economic Journal 130(May): 1008-1030.

Santos Silva, Joao M.C., and Silvana J. Tenreyro. 2006."The Log of Gravity.” The Review of Economics and Statistics 88(4): 641-658.

Santos Silva, Joao, and Silvana Tenreyro. 2010."On the Existence of the Maximum Likelihood Estimates in Poisson Regression."Economics Letters 107(2): 310-312.

Santos Silva, Joao, and Silvana Tenreyro. 2011."Further Simulation Evidence on the Performance of the Poisson Pseudo-Maximum Likelihood Estimator."Economics Letters 112(2): 220-222.

Subramanian, Arvind, and Shang-Jin Wei. 2007.“The WTO Promotes Trade Strongly but Unevenly.”Journal of International Economics 72(1): 151-175.

Sumner, Daniel A., Tristan Hanon, and William A. Matthews. 2019. "Implication of Trade Policy Turmoil for Perennial Crops." Choices, Quarter 4. http://www.choicesmagazine.org/choices-magazine/theme-articles/ the-economic-impacts-of-trade-retaliation-on-us-agriculture-a-one-year-review/implication-of-trade-policyturmoil-for-perennial-crops. Accessed December 19, 2020.

Taheripour, Farzad, and Wallace E. Tyner. 2018. "Impacts of Possible Chinese 25\% Tariff on U.S. Soybeans and Other Agricultural Commodities." Choices, Quarter 2. http://www.choicesmagazine.org/choices-magazine/ theme-articles/us-china-trade-dispute-and-potential-impacts-to-agriculture/impacts-of-possible-chinese-25-tariffon-us-soybeans-and-other-agricultural-commodities. Accessed December 19, 2020.

USDA. 2019. "Trade Damage Estimation for the 2019 Market Facilitation Program and Food Purchase and Distribution Program.” https://www.usda.gov/sites/default/files/documents/USDA_Trade_Methodology_ Report_2019.pdf. Accessed December 19, 2020.

Waugh, Michael E. 2019. "The Consumption Response to Trade Shocks: Evidence from the US-China Trade War.” Working Paper no. 26353, National Bureau of Economic Research.

Westhoff, Patrick, Tracy Davids, and Byung Min Soon. 2019. "Impacts of Retaliatory Tariffs on Farm Income and Government Programs" Choices, Quarter 4. http://www.choicesmagazine.org/choices-magazine/themearticles/the-economic-impacts-of-trade-retaliation-on-us-agriculture-a-one-year-review/impacts-of-retaliatorytariffs-on-farm-income-and-government-programs. Accessed December 19, 2020.

Yotov, Yoto V., Roberta Piermartini, Jose-Antonio Monteiro, and Mario Larch. 2016. "An Advanced Guide to Trade Policy Analysis: The Structural Gravity Model.” World Trade Organization. https://www.wto.org/ english/res_e/booksp_e/advancedwtounctad2016_e.pdf.

\section{SUPPORTING INFORMATION}

Additional supporting information may be found online in the Supporting Information section at the end of this article.

How to cite this article: Grant $\mathrm{JH}$, Arita S, Emlinger C, Johansson R, Xie C. Agricultural exports and retaliatory trade actions: An empirical assessment of the 2018/ 2019 trade conflict. Appl Econ Perspect Policy. 2021;1-22. https://doi.org/10.1002/aepp. $\underline{13138}$ 